\title{
Hubungan Panjang Badan Lahir dan Pemberian ASI Eksklusif dengan Kejadian Stunting pada Anak Usia 7-24 Bulan di Wilayah Kerja Puskesmas Seberang Padang
}

\author{
Putri Aisyah Mirza ${ }^{1}$, Delmi Sulastri ${ }^{2}$, Dessy Arisanty ${ }^{3}$ \\ ${ }^{1}$ Profesi Dokter FK UNAND (Fakultas Kedokteran Universitas Andalas), Padang \\ ${ }^{2}$ Bagian Gizi FK UNAND, Padang \\ ${ }^{3}$ Bagian Biomedik FK UNAND, Padang
}

\author{
A B S T R A C T
}

\begin{abstract}
Latar Belakang: Stunting adalah salah satu masalah gizi yang sering dijumpai pada anak. Stunting dapat menimbulkan gangguan pada pertumbuhan fisik serta perkembangan mental dan kecerdasan.

Objektif: Penelitian ini bertujuan untuk mengetahui hubungan antara panjang badan lahir dan pemberian ASI eksklusif dengan kejadian stunting pada anak usia 7-24 bulan di wilayah kerja Puskesmas Seberang Padang.

Metode: Penelitian ini adalah penelitian analitik observasional dengan desain cross sectional pada anak usia 7-24 bulan di wilayah kerja Puskesmas Seberang Padang yang dipilih melalui simple random sampling. Data yang digunakan adalah data hasil wawancara kuesioner dan hasil pengukuran panjang badan anak menggunakan infantometer. Analisis data dilakukan dengan uji chi square.

Hasil: Penelitian ini menemukan total 78 anak dengan prevalensi stunting sebanyak $22(28,2 \%)$, anak yang memiliki panjang badan lahir kurang sebanyak 28 (35,9\%), dan anak yang tidak mendapatkan ASI eksklusif sebanyak $45(57,7 \%)$. Analisis uji statistik menunjukkan hubungan yang tidak signifikan antara panjang badan lahir dengan stunting ( $p$-value $=0,464 ; 95 \% \mathrm{Cl}: 0,19-1,70)$, dan hubungan yang tidak signifikan antara pemberian ASI eksklusif dengan kejadian stunting ( $p$ value $=0,681 ; 95 \% \mathrm{Cl}: 0,51-3,89)$.
\end{abstract}

Kesimpulan: Tidak terdapat hubungan yang bermakna antara panjang badan lahir dan pemberian ASI eksklusif dengan kejadian stunting.

Kata kunci: ASI eksklusif, panjang badan lahir, stunting.

Background: Stunting is one of nutritional problems that commonly found in children. Stunting could affect to physical growth and also mental and intelligence development. Objective: To determine the association of birth length and exclusive breastfeeding with stunting in children aged 7-24 months in the working area of Seberang Padang Public Health Center.

Methods: This is an observasional study used a cross sectional approach on children aged 7-24 months in the working area of Seberang Padang Public Health Center who were selected by simple random sampling. Data was collected from administered questionnaire and measurement of height using infantometer. Data was analyzed by chi square test. PICU through 2015 2017. Samples were collected by the total sampling technique. Results: We found total 78 children with prevalence for stunting was 22 (28,2\%), children had short birth length was 28 (35,9\%), children had not gotten exclusive breastfeeding was 45 (57.7\%). Statistical analysis showed no significant relationship between birth length and stunting ( $p$-value = 0,464; 95\% Cl: 0,19-1,70), and no significant relationship between exclusive breastfeeding and stunting ( $p$-value = 0,681; 95\% Cl: 0,51-3,89).

Conclusion: There was no significant relationship between birth length and given exclusive breastfeeding with stunting.

Keyword: birth length, exclusive breastfeeding, stunting.

\section{Apa yang sudah diketahui tentang topik ini?}

Stunting mencerminkan efek kumulatif dari banyak faktor, diantaranya faktor rumah tangga dan keluarga (faktor ibu dan lingkungan rumah), pemberian ASI yang tidak adekuat, pemberian makanan pendamping yang tidak memadai, dan penyakit infeksi.

\section{Apa yang ditambahkan pada studi ini?}

Panjang badan lahir dan pemberian ASI eksklusif tidak berhubungan dengan kejadian stunting. Akan tetapi, anak yang memiliki panjang badan lahir normal tetapi tidak mendapat ASI eksklusif memiliki risiko stunting lebih tinggi dibanding yang mendapatkan ASI eksklusif.

\section{CORRESPONDING AUTHOR}

Phone: +6281261907741

E-mail: aisyahmirza1996@gmail.com

\section{ARTICLE INFORMATION}

Received: July $22^{\text {nd }}$, 2020

Revised: April $8^{\text {th }}, 2021$

Available online: May $27^{\text {th }}, 2021$ 


\section{Pendahuluan}

Indonesia merupakan negara berkembang yang memiliki permasalahan yang kompleks terutama masalah gizi. Salah satu masalah gizi yang dihadapi Indonesia saat ini adalah stunting, yaitu kondisi gagal tumbuh pada anak balita akibat dari kekurangan gizi kronis sehingga anak terlalu pendek untuk usianya. ${ }^{1}$

Stunting menjadi salah satu masalah gizi yang dialami balita saat ini. Data WHO menunjukkan 161 juta anak di dunia mengalami stunting pada tahun 2013 dan 150,8 juta (22,2\%) pada tahun 2017.2,3 Lebih dari setengah (55\%) balita yang mengalami stunting tinggal di Asia dan lebih dari sepertiganya (39\%) tinggal di Afrika. ${ }^{3}$ Indonesia merupakan negara ketiga dengan prevalensi stunting tertinggi di regional Asia Tenggara dengan rata-rata tahun 2005-2017 adalah 36,4\%. ${ }^{1}$

Stunting terjadi sebagai akibat kekurangan gizi dalam waktu lama terutama pada periode 1000 Hari Pertama Kehidupan (HPK) yakni 270 hari (9 bulan) masa kehamilan, ditambah 730 hari (usia 0-2 tahun) setelah anak lahir. Seribu HPK merupakan periode yang sangat kritis karena akibat yang ditimbulkan pada masa ini akan bersifat permanen dan sulit untuk diperbaiki. ${ }^{4}$ Akibat tersebut tidak hanya pada pertumbuhan fisik, tetapi juga pada perkembangan mental dan kecerdasannya. ${ }^{5}$

Data Riskesdas tahun 2018 menunjukkan prevalensi stunting pada balita di Indonesia sebesar 30,8\%. ${ }^{6}$ Angka ini meningkat dari tahun sebelumnya yaitu sebesar 29,6\%. Prevalensi stunting pada baduta di Indonesia tahun 2018 sebesar $29,9 \%{ }^{6}$

Salah satu faktor risiko dalam keterlambatan pertumbuhan ialah panjang badan bayi saat lahir. ${ }^{7}$ Panjang lahir bayi merupakan gambaran pertumbuhan linier bayi selama berada dalam kandungan. ${ }^{8}$ Bayi yang mengalami gangguan tumbuh (growth faltering) sejak usia dini berisiko mengalami growth faltering pula pada periode umur berikutnya sehingga menimbulkan terjadinya stunting. ${ }^{9}$ Prevalensi panjang lahir rendah $(<48 \mathrm{~cm})$ di Indonesia tahun 2013 sebesar $20,2 \%$, sedangkan di Sumatera Barat sebesar $15,5 \%{ }^{10}$

Penelitian Ni'mah di Surabaya pada tahun 2015 menunjukkan adanya hubungan bermakna antara panjang badan lahir dengan kejadian stunting pada balita. ${ }^{11}$ Penelitian lain oleh Utami et al. di Bogor tahun 2018 menemukan bahwa bayi dengan panjang lahir pendek memiliki risiko 1,6 kali lebih besar untuk mengalami stunting daripada bayi dengan panjang lahir normal. ${ }^{12}$

Bayi yang lahir normal tetapi asupan gizinya tidak adekuat juga dapat berisiko stunting. Kegagalan pertumbuhan ini sering dimulai dari dalam kandungan dan berlanjut setelah lahir akibat menyusui yang tidak optimal, makanan pendamping ASI yang tidak sesuai, dan kurangnya kontrol terhadap infeksi. ${ }^{13}$ ASI eksklusif merupakan makanan dan minuman utama bagi bayi baru lahir sampai usia enam bulan karena mengandung zat gizi yang ideal sesuai kebutuhan dan kemampuan pencernaan bayi. ASI mendukung pertumbuhan bayi terutama tinggi badan karena kalsium ASI lebih efisien diserap dibanding susu pengganti ASI. ${ }^{14}$

Penelitian Lestari di Aceh tahun 2014 menunjukkan bahwa anak yang tidak diberikan ASI eksklusif berisiko 6,54 kali menjadi stunting dibandingkan anak yang diberi ASI eksklusif. ${ }^{15}$ Penelitian lain oleh Ni'mah di Surabaya menunjukkan bahwa faktor utama yang berhubungan dengan kejadian stunting adalah ASI eksklusif $(\mathrm{OR}=4,643)$ dan panjang badan lahir $(\mathrm{OR}=4,091){ }^{11}$

Sumatera Barat merupakan provinsi di Indonesia dengan prevalensi stunting yang masih tinggi, yaitu 30,1\% pada tahun 2018. ${ }^{6}$ Data Dinas Kesehatan Kota Padang menunjukkan prevalensi balita stunting di Kota Padang tahun 2018 sebesar $7,65 \%$ dengan prevalensi tertinggi di Puskesmas Seberang Padang (23,04\%).16 Pemberian ASI eksklusif di wilayah kerja Puskesmas Seberang Padang mengalami penurunan dari tahun 2015 sampai tahun 2017, yaitu berturut-turut sebesar $96,67 \%, 93,1 \%$, dan $86,51 \% .16,17,18$

Berdarkan uraian di atas, peneliti tertarik untuk meneliti hubungan antara panjang badan lahir dan pemberian ASI eksklusif dengan kejadian stunting pada anak usia 7-24 bulan di wilayah kerja Puskesmas Seberang Padang.

\section{Metode}

Jenis penelitian ini adalah analitik observasional dengan rancangan cross sectional yaitu subyek penelitian diobservasi sebanyak satu kali dan variabel diukur langsung pada pemeriksaan tersebut. Variabel independennya adalah panjang badan lahir dan pemberian ASI

Putri Aisyah Mirza 
eksklusif dan variabel dependennya adalah stunting. Penelitian dilakukan dari bulan Oktober 2019 sampai dengan Februari 2020 di wilayah kerja Puskesmas Seberang Padang.

Populasi penelitian ini adalah anak usia 7-24 bulan di wilayah kerja Puskesmas Seberang Padang. Sampel penelitian yang dipilih adalah anak usia 7-24 bulan di wilayah kerja Puskesmas Seberang Padang yang memenuhi kriteria inklusi dan tidak memiliki kriteria eksklusi. Kriteria inklusi subjek: Anak usia 7-24 bulan; anak dan ibu berdomisili di wilayah kerja Puskesmas Seberang Padang; ibu bersedia menjadi responden penelitian; ibu mampu berkomunikasi dengan baik. Kriteria eksklusi subjek: Responden tidak berada di tempat sewaktu penelitian setelah tiga kali kunjungan; anak mengalami sakit berat, cacat fisik sehingga tidak bisa mengikuti penelitian; responden tidak mengetahui/lupa panjang badan lahir anak.

Data diperoleh dengan cara wawancara menggunakan kuesioner dan pengukuran langsung panjang badan anak dengan menggunakan length board. Data dianalisis secara statistik berdasarkan variabel yang dinilai menggunakan sistem komputerisasi yaitu analisis univariat dan bivariat. Analisis univariat dilakukan untuk melihat distribusi frekuensi dari masing-masing variabel independen dan variabel dependen. Analisis bivariat dilakukan untuk menganalisis hubungan antara variabel independen dan variabel dependen. Hubungan dua variabel tersebut dianalisis dengan menggunakan Continuity Correction dan dikatakan bermakna bila $\mathrm{p}<0.05$. Penelitian ini telah lulus kaji etik oleh Komite Etik Fakultas Kedokteran Universitas Andalas dengan nomor surat: 101/KEP/FK/2020.

\section{Hasil}

Penelitian ini dilakukan pada anak usia 7-24 bulan di wilayah kerja Puskesmas Seberang Padang. Sampel yang diteliti sebanyak 78 orang responden yang memenuhi kriteria inklusi dan tidak memiliki kriteria eksklusi.

\section{Karakteristik Responden}

Tabel 1. Distribusi Frekuensi Responden

\begin{tabular}{ccc}
\hline Karakteristik & $f$ & $\%$ \\
\hline Tingkat Pendidikan Ayah & & \\
a. Rendah & 22 & 28,2 \\
b. Sedang & 47 & 60,3 \\
\hline
\end{tabular}

264 Putri Aisyah Mirza

\begin{tabular}{ccc}
\hline Karakteristik & $f$ & $\%$ \\
\hline c. Tinggi & 9 & 11,5 \\
Tingkat Pendidikan Ibu & & \\
a. Rendah & 16 & 20,5 \\
b. Sedang & 43 & 55,1 \\
c. Tinggi & 19 & 24,4 \\
Jenis Pekerjaan Ayah & & \\
a. Jasa(ojek/supir)/bangunan & 34 & 43,6 \\
b. PNS/TNI/Polri & 3 & 3,8 \\
c. Pegawai Swasta & 16 & 20,5 \\
d. Dagang/wiraswasta & 25 & 32,1 \\
Jenis Pekerjaan Ibu & & \\
a. Tidak bekerja & 63 & 80,8 \\
b. Jasa(ojek/supir)/bangunan & 2 & 2,6 \\
c. PNS/TNI/Polri & 2 & 2,6 \\
d. Pegawai Swasta & 5 & 6,4 \\
e. Dagang/wiraswasta & 6 & 7,7 \\
Pendapatan Keluarga & & \\
a. Rendah (< UMR) & 31 & 39,7 \\
b. Tinggi ( $\geq$ UMR) & 47 & 60,3 \\
Jenis Kelamin Anak & & \\
a. Laki-laki & 38 & 48,7 \\
b. Perempuan & 40 & 51,3 \\
Masa Kehamilan & & \\
a. Kurang Bulan (<37 minggu) & 17 & 21,8 \\
b. Cukup Bulan ( $\geq 37$ minggu) & 61 & 78,2 \\
Berat Badan Lahir & & \\
a. BBLR (<2500 gram) & 74 & 94,9 \\
b. Normal ( $\geq 2500$ gram) & & \\
\hline & & \\
\hline
\end{tabular}

Tabel 1 menunjukkan bahwa lebih dari separuh sampel memiliki ayah dengan tingkat pendidikan sedang $(60,3 \%)$, dan lebih dari separuh ibu memiliki tingkat pendidikan sedang $(55,1 \%)$. Semua ayah sampel memiliki pekerjaan dengan pekerjaan paling banyak adalah jasa (ojek/supir/bangunan) yaitu sebesar 43,6\%, sedangkan ibu sampel sebagian besar tidak bekerja atau ibu rumah tangga $(80,8 \%)$. Lebih dari separuh sampel berasal dari keluarga dengan pendapatan perbulan yang tergolong tinggi (60,3\%).

Pada penelitian ini, lebih dari separuh sampel berjenis kelamin perempuan yaitu sebanyak 40 anak (51,3\%), dan sisanya 38 anak $(48,7 \%)$ berjenis kelamin laki-laki. Sebagian besar sampel lahir dengan masa kehamilan cukup bulan $(78,2 \%)$. Pada umumnya sampel lahir dengan berat badan lahir normal $(94,9 \%)$. 


\section{Kejadian Stunting}

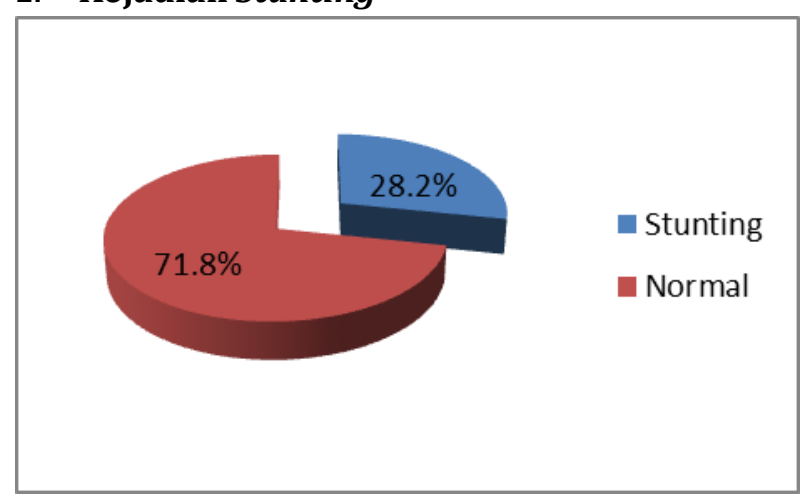

Gambar 1. Distribusi Frekuensi Kejadian Stunting

Pada penelitian ini didapatkan hampir sepertiga sampel penelitian memiliki status gizi stunting yaitu $28,2 \%$.

\section{Panjang Badan Lahir}

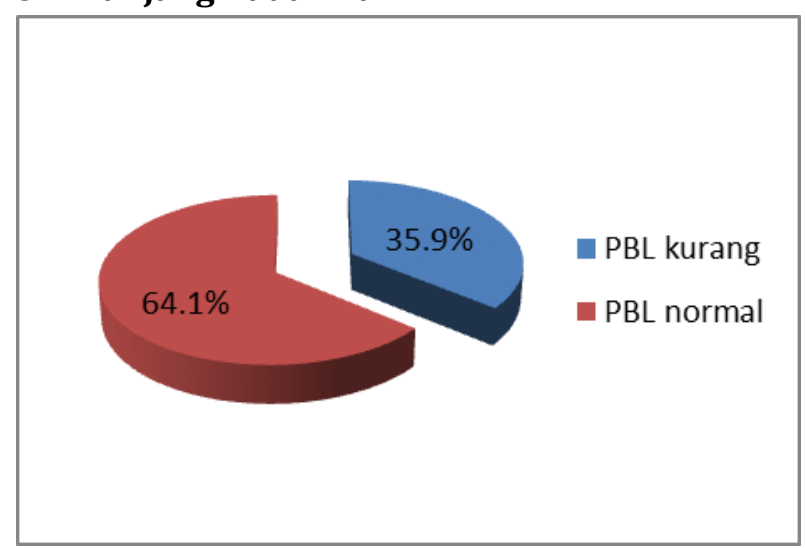

Gambar 2. Distribusi Frekuensi Panjang Badan Lahir

Pada penelitian ini didapatkan lebih dari separuh sampel lahir dengan panjang badan lahir normal yaitu $64,1 \%$.

\section{ASI Eksklusif}

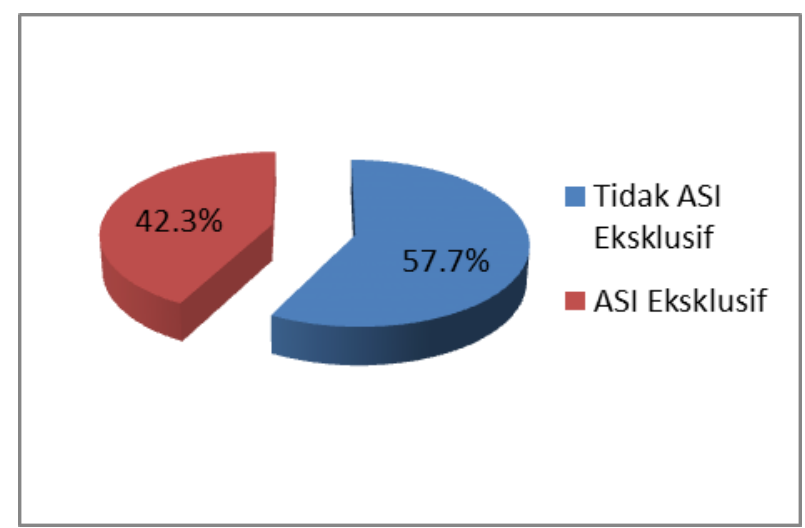

Gambar 3. Distribusi Frekuensi Pemberian ASI Eksklusif

Pada penelitian ini didapatkan lebih dari separuh sampel tidak mendapatkan ASI eksklusif yaitu $57,7 \%$.

\section{Hubungan Panjang Badan Lahir dan ASI Eksklusif dengan Kejadian Stunting}

Tabel 2. Hubungan Panjang Badan Lahir dan ASI Eksklusif dengan Kejadian Stunting

\begin{tabular}{|c|c|c|c|c|c|c|c|c|}
\hline \multirow{3}{*}{ Variabel } & \multicolumn{4}{|c|}{ Kejadian Stunting } & \multirow{2}{*}{\multicolumn{2}{|c|}{ Total }} & \multirow{3}{*}{$\begin{array}{c}\text { OR } \\
(95 \% \mathrm{CI})\end{array}$} & \multirow{3}{*}{$p$-value } \\
\hline & \multicolumn{2}{|c|}{ Stunting } & \multicolumn{2}{|c|}{ Normal } & & & & \\
\hline & $\mathrm{f}$ & $\%$ & $\mathrm{f}$ & $\%$ & $f$ & $\%$ & & \\
\hline \multicolumn{9}{|c|}{ Panjang Badan Lahir } \\
\hline Kurang & 6 & 21,4 & 22 & 78,6 & 28 & 100 & 0,58 & \multirow{2}{*}{0,464} \\
\hline Normal & 16 & 32,0 & 34 & 68,0 & 50 & 100 & $(0,19-1,70)$ & \\
\hline \multicolumn{9}{|c|}{ ASI Eksklusif } \\
\hline Tidak & 14 & 31,1 & 31 & 68,9 & 45 & 100 & 1,41 & \multirow{2}{*}{0,681} \\
\hline Ya & 8 & 24,2 & 25 & 75,8 & 33 & 100 & $(0,51-3,89)$ & \\
\hline
\end{tabular}

Pada tabel uji silang tidak terdapat sel yang memiliki frekuensi harapan (expected count) kurang dari 5. Oleh karena itu, digunakan uji ChiSquare yaitu Continuity Correction.

Hasil uji statistik untuk panjang badan lahir diperoleh nilai $\mathrm{p}=0,464 \quad(\mathrm{p}>0,05)$. Berdasarkan hasil tersebut dapat disimpulkan secara statistik bahwa tidak terdapat hubungan yang bermakna antara panjang badan lahir dengan kejadian stunting. Hasil uji statistik untuk ASI eksklusif diperoleh nilai $\mathrm{p}=0,681 \quad(\mathrm{p}>0,05)$. Berdasarkan hasil tersebut dapat disimpulkan secara statistik bahwa tidak terdapat hubungan yang bermakna antara pemberian ASI eksklusif dengan kejadian stunting.

\section{Pembahasan}

Stunting didefinisikan sebagai tinggi badan menurut umur (TB/U) berada di bawah -2 SD berdasarkan median standar pertumbuhan anak WHO.1 Pada penelitian ini ditemukan sebesar 28,2\% anak usia 7-24 bulan di wilayah kerja Puskesmas Seberang Padang memiliki status gizi stunting. Hal ini menunjukkan bahwa kejadian stunting pada anak di wilayah kerja Puskesmas Seberang Padang telah menjadi masalah kesehatan masyarakat, karena melebihi batas yang telah ditetapkan oleh WHO yaitu sebesar $20 \%$.

Prevalensi stunting pada penelitian ini juga lebih tinggi dibandingkan dengan data Dinas Kesehatan Kota Padang tahun 2018 dimana kejadian stunting pada balita di Puskesmas Seberang Padang sebesar 23,04\%. ${ }^{16}$ Perbedaan hasil ini dapat disebabkan oleh perbedaan populasi dan besarnya populasi yang diteliti. Data Dinas Kesehatan Kota Padang didasarkan kepada 
catatan atau laporan setiap anggota yang diambil dari tiap posyandu, sedangkan populasi pada penelitian ini ialah anak dengan kelompok usia 7 sampai 24 bulan yang terikat dengan kriteria inklusi dan jumlah sampel penelitian.

Tingginya angka kejadian stunting pada penelitian ini dapat disebabkan oleh faktor pendidikan ibu. Pada penelitian ini sebagian besar tingkat pendidikan ibu berada dalam kategori rendah dan sedang. Tingkat pendidikan turut menentukan mudah tidaknya seseorang dalam menyerap dan memahami pengetahuan gizi yang didapatkan. ${ }^{11}$ Pengetahuan ibu mengenai gizi akan berpengaruh terhadap sikap dan perilaku dalam pemilihan bahan makanan, yang selanjutnya akan memengaruhi keadaan gizi keluarganya. ${ }^{11}$ Orang yang berpendidikan lebih tinggi cenderung untuk memilih bahan makanan yang lebih baik dalam hal kualitas dan kuantitas hidangan dibandingkan dengan mereka yang berpendidikan rendah atau sedang. ${ }^{19}$ Semakin tinggi tingkat pendidikan ibu maka akan semakin baik pula status gizi anaknya.

Panjang badan lahir adalah ukuran panjang bayi yang dilakukan secara telentang ketika bayi dilahirkan. Panjang badan bayi saat lahir menggambarkan pertumbuhan linear yang dialami bayi selama dalam kandungan. Ukuran linear yang rendah biasanya menunjukkan keadaan gizi yang kurang akibat kekurangan energi dan protein pada masa lampau. Asupan gizi yang kurang adekuat pada masa kehamilan menyebabkan perlambatan atau retardasi pertumbuhan janin sehingga dapat menyebabkan bayi lahir dengan panjang badan lahir kurang. ${ }^{8}$ Bayi dikatakan memiliki panjang badan lahir (PBL) kurang apabila bayi tersebut lahir dengan panjang badan kurang dari $48 \mathrm{~cm} .{ }^{20}$

Pada penelitian ini ditemukan anak yang memiliki panjang badan lahir normal lebih banyak dibandingkan dengan panjang badan lahir kurang, yaitu sebesar $64,1 \%$ anak lahir dengan panjang badan lahir normal dan 35,9\% anak lahir dengan panjang badan lahir kurang. Hasil yang tak jauh berbeda didapatkan pada penelitian oleh Juniar (2019) di Purworejo dimana 37,0\% anak memiliki panjang badan lahir kurang dan 63\% lainnya memiliki panjang badan lahir normal. ${ }^{21}$ Akan tetapi proporsi panjang badan lahir kurang pada penelitian ini lebih tinggi dibandingkan penelitian Illahi di Bangkalan (2017) yang menemukan anak dengan panjang badan lahir kurang sebesar 9,7\% dan panjang lahir normal sebesar 90,3\%.22 Hasil ini juga lebih tinggi dibandingkan dengan data nasional dimana prevalensi panjang badan lahir kurang di Indonesia tahun 2018 sebesar 22,7\%.23

Tingginya proporsi panjang badan lahir kurang dapat dipengaruhi oleh usia kehamilan saat anak lahir. Pada penelitian ini ditemukan sebanyak 21,8\% anak lahir dengan kehamilan kurang bulan atau preterm (usia kehamilan $<37$ minggu) sedangkan pada penelitian Illahi anak yang lahir pada usia kehamilan kurang bulan sebesar 6,5\%. Menurut Prawiroharjo dalam Sentana (2018), persalinan preterm bisa menjadi penyebab kurangnya asupan nutrisi janin sehingga kondisi bayi ketika dilahirkan memiliki panjang badan lahir yang tidak normal. ${ }^{24}$ Hal ini disebabkan kebutuhan gizi bayi yang dilahirkan pada persalinan preterm masih belum terpenuhi secara optimal karena usia kehamilan yang belum cukup bulan. ${ }^{24}$

ASI eksklusif adalah ASI yang diberikan kepada bayi sejak dilahirkan selama enam bulan, tanpa menambahkan dan/atau mengganti dengan makanan atau minuman lain. ${ }^{25}$ Hasil penelitian ini menunjukkan bahwa separuh lebih anak usia 7-24 bulan di wilayah kerja Puskesmas Seberang Padang tidak mendapatkan ASI eksklusif yaitu $57,7 \%$, sedangkan sisanya $42,3 \%$ anak mendapatkan ASI eksklusif. Hasil ini sejalan dengan penelitian yang dilakukan oleh Lestari (2014) di Kecamatan Penanggalan Aceh dimana anak yang tidak mendapatkan ASI eksklusif lebih banyak (52,7\%) dibandingkan dengan anak yang mendapatkan ASI eksklusif (47,3\%). ${ }^{15}$ Akan tetapi, cakupan pemberian ASI eksklusif pada penelitian ini lebih rendah dibandingkan dengan cakupan ASI eksklusif di Indonesia tahun 2018 yaitu sebesar $68,74 \% .^{6}$

Rendahnya cakupan pemberian ASI eksklusif disebabkan oleh kondisi ibu yang tidak memungkinkan untuk memberi ASI saja kepada anaknya yaitu terdapat permasalahan ASI sulit keluar atau sedikit sehingga ibu memberikan minuman lain kepada anaknya. Selain itu adanya persepsi yang salah di masyarakat dimana ibu menganggap bahwa bayi menangis karena merasa lapar disebabkan jumlah ASI yang tidak cukup sehingga ibu memberikan tambahan makanan bayi, di samping ASI. Hal ini juga dipengaruhi oleh kebiasaan di dalam keluarga untuk memberi 
makanan/minuman lain selain ASI sebelum anak berusia 6 bulan.

Hasil analisis bivariat menunjukkan tidak terdapat hubungan yang bermakna antara panjang badan lahir dengan kejadian stunting pada anak usia 7-24 bulan di wilayah kerja Puskesmas Seberang Padang, ditandai dengan nilai $p=0,464 \quad(p>0,05)$. Penelitian ini sejalan dengan penelitian Sentana (2018) di Pekanbaru dimana panjang badan lahir tidak memiliki hubungan yang signifikan dengan kejadian stunting. ${ }^{24}$ Hasil serupa juga ditemukan pada penelitian oleh Rukmana (2016) di Bogor yang menunjukkan bahwa panjang lahir tidak berhubungan dengan kejadian stunting pada anak usia 6-24 bulan. ${ }^{26}$

Hasil ini berbeda dengan penelitian yang dilakukan oleh Utami (2018) terhadap 320 anak usia 0-23 bulan di Bogor. Utami menyebutkan bahwa anak dengan panjang badan lahir kurang akan berisiko untuk mengalami stunting. ${ }^{12}$ Penelitian lain oleh Ni'mah (2015) di Surabaya menunjukkan hubungan yang bermakna antara panjang badan lahir dengan kejadian stunting, dimana anak dengan panjang badan lahir kurang ( $<48 \mathrm{~cm}$ ) berisiko mengalami stunting 4,091 kali lebih besar daripada anak dengan panjang badan lahir normal $(\geq 48 \mathrm{~cm}) .{ }^{11}$

Perbedaan hasil pada penelitian ini dapat disebabkan karena orang tua yang memiliki anak dengan panjang badan lahir kurang telah melakukan perbaikan gizi terhadap anaknya sehingga pertumbuhan normal dapat terkejar. Menurut Kiely dalam Nugroho (2016), faktor asupan dan penyakit memiliki peranan penting dalam mengetahui apakah anak dengan panjang badan lahir yang pendek akan tetap stunting selama hidupnya atau dapat mencapai catch up growth yang maksimal.27 Selama anak mendapatkan asupan gizi yang memadai dan terjaga kesehatannya, maka kondisi anak yang lahir dengan panjang badan yang pendek dapat dikejar pertumbuhannya seiring dengan bertambahnya usia anak. ${ }^{27}$ Asupan gizi pada anak dapat dilihat dari pemberian ASI eksklusif. Pada penelitian ini didapatkan bahwa anak yang lahir dengan panjang badan lahir normal tetapi tidak mendapatkan ASI eksklusif memiliki angka stunting lebih tinggi (35,7\%) dibandingkan dengan anak yang mendapatkan ASI eksklusif $(27,3 \%)$. Sedangkan pada anak yang lahir dengan panjang badan lahir kurang tetapi mendapatkan ASI eksklusif memiliki angka stunting lebih kecil $(18,2 \%)$ dibandingkan dengan anak yang tidak mendapatkan ASI eksklusif (23,5\%). Artinya adalah meskipun anak lahir dengan panjang badan lahir normal tetapi tidak diimbangi dengan pemberian asupan gizi yang adekuat maka masih berisiko untuk menjadi stunting.

Hasil penelitian ini menunjukkan bahwa ASI eksklusif tidak berhubungan dengan kejadian stunting pada anak usia 7-24 bulan di wilayah kerja Puskesmas Seberang Padang. Hal ini dapat dilihat dari hasil uji statistik yaitu diperoleh nilai $p=0,681(p>0,05)$. Penelitian ini sejalan dengan penelitian Bertalina di Kecamatan Kemiling Lampung tahun 2018 yang menunjukkan tidak ada hubungan bermakna antara pemberian ASI eksklusif dengan kejadian stunting. ${ }^{28}$ Akan tetapi, penelitian ini tidak sejalan dengan penelitian oleh Lestari di Aceh tahun 2014 yang melaporkan bahwa ASI eksklusif berhubungan dengan kejadian stunting pada anak usia 6-24 bulan. Lestari mengemukakan bahwa anak yang tidak mendapatkan ASI eksklusif berisiko menjadi stunting 6,54 kali dibandingkan dengan anak yang diberi ASI eksklusif. ${ }^{15}$

Pemberian ASI ekslusif tidak berhubungan dengan kejadian stunting dapat disebabkan karena stunting tidak hanya dipengaruhi oleh faktor pemberian ASI eksklusif, tetapi juga dipengaruhi oleh banyak faktor lain seperti kualitas makanan pendamping ASI (MP-ASI), kecukupan zat gizi yang diberikan kepada anak setiap hari, serta status kesehatan bayi. ${ }^{29}$ Sampel pada penelitian ini ialah anak yang berumur di bawah dua tahun (baduta). Periode umur ini disebut dengan masa kritis, yaitu masa saat anak akan mengalami tumbuh kembang dan tumbuh kejar. Anak yang mengalami kekurangan gizi sebelumnya masih dapat diperbaiki dengan asupan yang baik sehingga dapat melakukan tumbuh kejar sesuai dengan perkembangannya. Begitu pula dengan anak yang normal kemungkinan terjadi gangguan pertumbuhan apabila asupan yang diterima tidak mencukupi. ${ }^{29}$ Artinya adalah anak yang tidak mendapat ASI eksklusif selama 6 bulan pertama dapat tumbuh dan berkembang dengan baik apabila pemenuhan kebutuhan gizi selanjutnya terpenuhi dengan baik.

Pada penelitian ini didapatkan bahwa meskipun ASI eksklusif tidak berhubungan 
dengan kejadian stunting tetapi proporsi stunting lebih banyak terjadi pada anak yang tidak mendapatkan ASI eksklusif $(31,1 \%)$ dibandingkan dengan anak yang mendapatkan ASI eksklusif $(24,2 \%)$. Selain itu diperoleh nilai $\mathrm{OR}=1,41$ yang berarti anak dengan ASI tidak eksklusif memiliki kemungkinan risiko 1,41 kali lebih besar untuk mengalami stunting dibandingkan anak dengan ASI eksklusif. Hal ini menunjukkan bahwa dengan pemberian ASI eksklusif kepada bayi dapat mengurangi kemungkinan kejadian stunting pada anak.

\section{Simpulan}

Berdasarkan hasil penelitian ini didapatkan kesimpulan bahwa prevalensi panjang badan lahir kurang pada anak usia 7-24 bulan di wilayah kerja Puskesmas Seberang Padang lebih tinggi dibandingkan data nasional. Cakupan pemberian ASI eksklusif pada penelitian ini lebih rendah dibandingkan rata-rata nasional. Kejadian stunting pada penelitian ini melebihi batas yang telah ditetapkan oleh WHO. Panjang badan lahir dan pemberian ASI eksklusif tidak memiliki hubungan yang bermakna dengan kejadian stunting pada anak usia 7-24 bulan di wilayah kerja Puskesmas Seberang Padang.

\section{Ucapan Terima Kasih}

Terima kasih penulis sampaikan kepada semua instansi yang telah membantu penyelesaian penelitian ini.

\section{Daftar Pustaka}

1. Kemenkes RI. Situasi balita pendek (Stunting) di Indonesia. Buletin Jendela Data dan Informasi Kesehatan. 2018;301(5):1163-1178.

2. de Onis M, Branca F. Childhood stunting: A global perspective. Matern Child Nutr. 2016;12:12-26.

3. UNICEF, WHO WBG. Levels and trends in child malnutrition. 2018;1-15.

4. Kemenkes RI. Cegah stunting itu penting. Warta Kesmas. 2018.

5. Kemenkokesra. Kerangka kebijakan gerakan 1000 hari pertama kehidupan. Jakarta: Kemenkokesra RI; 2012.

6. Kemenkes RI. Profil kesehatan Indonesia 2018. Jakarta: Kemenkes RI; 2019.

7. Swathma D, Lestari H, Ardiansyah RT. Analisis faktor risiko bblr, panjang badan bayi saat lahir dan riwayat imunisasi dasar terhadap kejadian stunting pada balita usia 12-36 bulan di wilayah kerja Puskesmas Kandai Kota Kendari tahun 2016 (Skripsi). Fakultas Kesehatan Masyarakat Universitas Halu Oleo; 2016.

8. Supariasa IDN, Bakri B, Fajar I. Penilaian status gizi. Jakarta: EGC; 2002.
9. Anugraheni HS, Kartasurya MI. Faktor risiko kejadian stunting pada anak usia 12-36 bulan di Kecamatan Pati, Kabupaten Pati. J Nutr Coll. 2012;1(1):30-7.

10. Trihono, Atmarita, et al. Pendek (Stunting) di Indonesia, masalah dan solusinya. Jakarta: Lembaga Penerbit Balitbangkes; 2015.

11. Ni'mah K, Nadhiroh SR. Faktor yang berhubungan dengan kejadian stunting pada balita. Media Gizi Indones. 2015;10(1):13-9.

12. Utami NH, Rachmalina R, et al. Short birth length, low birth weight and maternal short stature are dominant risks of stunting among children aged 0-23 months: Evidence from Bogor longitudinal study on child growth and development, Indonesia. Malays J of Nutr. 2018;24(1):11-23.

13. Weise AS. Stunting policy brief. WHO Global Nutrition Targets 2025. Switzerland: Geneva; 2014.

14. Indrawati S. Hubungan pemberian ASI esklusif dengan kejadian stunting pada anak usia 2-3 tahun di Desa Karangrejek Wonosari Gunungkidul (Skripsi). Universitas 'Aisyiyah Yogyakarta; 2016.

15. Lestari W, Margawati A, Rahfiludin MZ. faktor risiko stunting pada anak umur 6-24 bulan di Kecamatan Penanggalan Kota Subulussalam Provinsi Aceh. J Gizi Indones. 2014;3(1):37-45.

16. Dinas Kesehatan Kota Padang. Profil kesehatan kota Padang tahun 2018. Padang: Dinas Kesehatan Kota Padang; 2019.

17. Dinas Kesehatan Kota Padang. Profil kesehatan kota Padang tahun 2017. Padang: Dinas Kesehatan Kota Padang; 2018.

18. Dinas Kesehatan Kota Padang. Profil kesehatan kota Padang tahun 2015. Padang: Dinas Kesehatan Kota Padang; 2016.

19. Sulastri D. Faktor Determinan Kejadian Stunting pada Anak Usia Sekolah di Kecamatan Lubuk Kilangan Kota Padang. Maj Kedokt Andalas. 2012;36(1):39-50.

20. Kemenkes RI. Panduan pelayanan kesehatan bayi baru lahir berbasis perlindungan anak. Jakarta: Kemenkes RI; 2010.

21. Juniar D, P DR, Rahfiludin MZ. Faktor-faktor yang berhubungan dengan status gizi bayi usia 0-6 bulan (studi kasus di wilayah kerja Puskesmas Gebang, Kecamatan Gebang, Kabupaten Purworejo). J Kesehat Masy. 2019;7(1):289-296.

22. Illahi RK. Hubungan pendapatan keluarga, berat lahir, dan panjang lahir dengan kejadian stunting balita 2459 bulan di Bangkalan. J Manaj Kesehat. 2017;3(1):114.

23. Kemenkes RI. RISKESDAS 2018. Jakarta: Balitbang Kemenkes RI; 2018.

24. Sentana LF, Hrp JR, Hasan Z. Faktor-faktor yang berhubungan dengan kejadian stunting pada anak usia 12-24 bulan di Kelurahan Kampung Tengah Kecamatan Sukajadi Pekanbaru. J Ibu dan Anak. 2018;6(1):1-9.

25. Presiden RI. Peraturan pemerintah Republik Indonesia nomor 33 tahun 2012 tentang pemberian air susu ibu eksklusif. Jakarta; 2012.

26. Rukmana E, Briawan D, Ekayanti I. Faktor risiko stunting pada anak usia 6-24 bulan di Kota Bogor. J MKMI. 2016;12(3):192-199.

27. Nugroho A. Determinan growth failure (stunting) pada anak umur $1 \mathrm{~s} / \mathrm{d} 3$ tahun (studi di Kecamatan Tanjungkarang Barat Kota Bandar Lampung). J Kesehat. 2016;7(3):470-479. 
28. Bertalina, P.R A. Hubungan asupan gizi, pemberian asi eksklusif, dan pengetahuan ibu dengan status gizi (tb/u) balita 6-59 bulan. J Kesehat. 2018;9(1):117.

29. Hindrawati $N$, Rusdiarti. Gambaran riwayat pemberian asi eksklusif dengan kejadian stunting pada anak usia 6-24 bulan di Desa Arjasa Kecamatan Arjasa Kabupaten Jember. JKAKJ. 2018;2(1):1-7. 